\title{
Optimization of Real-Time Control with Green and Grey Infrastructure Design for a Cost-Effective Mitigation of Combined Sewer Overflows
}

\author{
Marie-Ève Jean', Camille Morin¹, Sophie Duchesne', Geneviève Pelletier² and Martin \\ Pleau $^{3}$
}

${ }^{1}$ Institut national de la recherche scientifique, Centre Eau Terre Environnement, 490, rue de la couronne, Québec (QC), G1K 9A9, Canada

${ }^{2}$ Univeristé Laval, Département de génie civil et de génie des eaux, 1065 Avenue de la

Médecine, Québec (QC), G1V 0A6, Canada

${ }^{3}$ Tetra Tech QI inc., 4655, boul. Wilfrid-Hamel, Québec (QC), G1P 2J7, Canada

Corresponding author: Marie-Ève Jean (Marie-Eve.Jean@ete.inrs.ca)

Key Points:

- Green and grey infrastructure design and real-time control rules optimization are applied to improve management of combined sewer overflows

- Simulations and optimizations are performed on a case study watershed for two design storms and for a period from 2006 to 2015

- Integration of real-time control with green and grey infrastructure is the most costeffective option given performance uncertainty

\section{Abstract}

An innovative optimization-simulation framework is applied to a case study of the Province of Quebec, Canada, to optimize the spatial distribution of green infrastructure (GI), the capacity and location of grey infrastructure and the parameters specific to real-time control (RTC) operating rules of a sewer system for reducing combined sewer overflows (CSOs) frequency and volume. GI, grey infrastructure and RTC are applied either individually or in integration through eight optimization scenarios which are simulated over a nine-year period of historical rainfall data. Among all scenarios, spatial optimization of GI with RTC leads to maximal CSO volume re duction $(98 \%)$ and is the most cost-effective option analyzed $\left(70 \$ / \mathrm{m}^{3}\right.$ of seasonal average CSO . duction compared to $140 \$ / \mathrm{m}^{3}$ for the scenario involving grey infrastructure alone). However, it requires a high GI implantation level and the CSO frequency under this scenario is sensitive to varying GI design parameters. The findings suggest that the best alternative for CSO control is the integration of the optimization of green and grey infrastructures with RTC as it still provides high CSO volume reduction (95\%) and remains a cost-effective solution $\left(90 \$ / \mathrm{m}^{3}\right.$ of CSO reduction), while providing robustness under cost and design uncertainties.

\section{Plain Language Summary}

An innovative method is applied to a case study of the Province of Quebec, Canada, to optimize the spatial distribution of green infrastructure (GI), the volume and location of storage facilities and the operational rules of a smart control strategy of a sewer network for reducing the number and volume of overflows of untreated wastewater (CSO) during rainfall events. GI, storage facilities and smart control strategy are applied either individually or in different combinations through eight different scenarios. Spatial optimization of GI with smart control leads to maximal 
CSO volume reduction $(98 \%)$ at the lowest cost $\left(70 \$ / \mathrm{m}^{3}\right.$ of seasonal average CSO reduction compared to $140 \$ / \mathrm{m}^{3}$ for the scenario involving storage facilities alone) as compared to other options, but requires a high GI implantation level and the GI design parameters can considerably impact its performance. The results suggest that the best alternative for CSO control, providing robustness under cost and design uncertainty, is the integration of the optimization of GI and storage facilities with smart control as it still provides high CSO volume reduction (95\%) and remains a cost-effective solution ( $90 \$ / \mathrm{m}^{3}$ of CSO reduction).

\section{Introduction}

Combined sewer networks are sewage systems that collect both wastewater and stormwater in the same pipe network. These systems were commonly constructed in many cities of the developed and developing world up to the mid-twentieth century (Burian et al., 1999). Due to the high variability in stormwater volume and flowrate that characterize urban areas, the wastewater treatment capacity and/or transport capacity of these networks were not designed to cope with the magnitude of most rainfall events, excepting the most frequent, smaller ones. This type of combined system thus permits overflows or spill of a mix of wastewater and stormwater to the environment; these are known as combined sewer overflows (CSOs). CSOs have been recognized as one of the major causes of degraded water quality in urban rivers (Bi et al., 2015; Passerat et al., 2011), contributing to the degradation of aquatic habitats, increasing drinking water treatment cost and reducing the attractiveness of aquatic recreational activities (MadouxHumery et al., 2015). The environmental, economic and social impacts of CSOs are associated with corresponding policies to limit CSO event frequency, volume and/or pollutant load (Tibbetts, 2005; Osseyrane, 2014). For instance, in the Province of Quebec (Canada), since 2014, all sewer extension projects must demonstrate compensatory actions to avoid increasing the seasonal frequency of CSO events (MELCC, 2014). In addition, the government plans to reduce CSO frequency down to a fixed limit determined for each receiving water body for the 2040s horizon. In this context, municipal actions are required to cope with CSO regulations in the most cost-efficient manner.

Among the existing solutions available for controlling urban runoff and resulting CSO impacts to the environment, many researchers are promoting source control of stormwater, including Green Infrastructure (GI) practices in contrast with traditional grey infrastructure practices involving the construction of large-scale retention infrastructure (Alves et al., 2016; Tavakol-Davani et al., 2015; Joshi et al., 2021). A variety of terminologies are associated with source controls, including GI, low impact development (LID), Source control measures (SCM), Sustainable urban drainage systems (SUDs), etc., but all these terms generally mean that runoff is managed as close to the source as possible, with the goal of replicating predevelopment conditions (Fletcher et al., 2015). Common source control measures include bioretention cells, rain gardens, permeable pavement and green roofs which are implemented to capture and treat runoff from surrounding impervious surfaces or simply to reduce the area of impervious surfaces. These approaches are recognized for their numerous transversal benefits, such as improving the urban landscape aesthetic and natural water balance, providing some water treatment through natural processes and reducing the community's vulnerability to climate change (Dagenais et al., 2014). In general, these infrastructure practices involve either infiltration, retention or a combination of both processes for accumulating runoff, before releasing it more gradually in the network or through infiltration and evaporation losses in the environment (Eckart, 2017).

This article is protected by copyright. All rights reserved. 
Different studies assessed the potential of applying a large number of GI units at the watershed scale for reducing CSO impact. In particular, many studies demonstrated CSO volume reductions (Mailhot et al., 2014; Patwardhan et al., 2005; Radinja et al., 2018; McGarity et al., 2017; Joshi et al., 2021, Torres et al., 2018), or both CSO volume and frequency reductions (Alves et al., 2016; Lucas and Sample, 2015). Moreover, CSO control can be improved under high implementation level of GIs (Autixier et al., 2014; Chaosakul et al., 2013; Smullen et al., 2008; Stovin et al., 2013) or when grey infrastructures (i.e. storage tanks) are combined with GIs (Alves et al., 2016, Dong et al., 2017; Montalto et al., 2007; Liao et al., 2015, Fu et al., 2019; Tavakol-Davani et al., 2016). A few authors also applied various optimization techniques to quantify and locate GI practices at the lowest cost possible while mitigating either peak flows in combined sewer networks (Sebti et al., 2016) or CSO volumes (Fu et al., 2019; Joshi et al., 2021; Torres et al., 2018). In general, past studies found that GI leads to reductions in the investment costs for CSO control as compared to grey infrastructures (Joshi et al., 2021, Lia et al., 2015; Montalto et al., 2007).

The use of real-time control (RTC) techniques with the aim of improving the use of existing sewer network capacity for CSO control have also been largely studied in the past (Schutze et al., 2004). RTC management involves dynamic control of the network infrastructure based on real-time measurements or predictions of process variables, such as rainfall intensity, water levels, and flowrates, amongst others. RTC strategies can be developed to meet either local or global performance objectives and can rely on various control algorithms such as rule-based derived methods (i.e. if-then-else rules) or more complex optimization-based approaches (i.e. model predictive control) (Lund et al., 2018; García et al., 2015). RTC can also be reactive if only real-time measurements of the current state of the system are considered as the input variables or predictive if rainfall forecasts are also included as an input of the decision rules (Shishegar et al., 2018). The scientific literature reports that RTC management is a cost-efficient solution for CSO volume and frequency reduction, both from the perspective of real-world applications (Entem et al., 1998; Fuchs et al., 2005; Pleau et al., 2005; Seggelke et al., 2013) and theoretical studies (Dirckx et al., 2011; Joseph-Duran et al., 2018; Kroll, 2019; Maiolo et al., 2020; Nielsen et al., 2010).

As suggested by Piro et al. (2019), RTC and GIs are the newest and most adequate techniques to alleviate urban drainage problems. Indeed, a few research works were conducted to evaluate the joined impact of applying RTC on the network and distributing GI over the watershed area; they showed improved CSO volume reductions (Frehmann et al., 2002, Altobelli et al., 2020) and improved cost effectiveness (Frey et al., 2013) under the joined solutions scenarios. More recently, it has been suggested that source control measures performance could largely benefit from RTC technologies for improving operational control on site (Xu et al., 2020; Brasil et al., 2021). More particularly, studies demonstrated greater CSO volume reductions (Lund et al., 2019; Oberascher et al., 2021), or both CSO volume and frequency reductions (Lewellyn, 2018; Lucas \& Sample, 2015) when GI are dynamically controlled compared to passive GI design.

Whereas previous studies highlighted the potential of optimizing the spatial distribution of GI for CSO abatement, and the added benefit of combining RTC and grey infrastructure within the network or RTC and GIs on site, only a few research works analyzed the combined impact of RTC of the network with GI. More importantly, none of them considered the impact of RTC of the network while optimizing the spatial distribution of GI.

This article is protected by copyright. All rights reserved. 
This research was conducted with an overarching goal of integrating the optimization of RTC, GI spatial distribution and grey infrastructure design volumes to reduce CSO frequency and volume, and simultaneously reduce costs. The hypothesis guiding this research work is, on one hand, the fact that RTC decisions are greatly influenced by the quantity, timing and spatial distribution of the runoff entering the combined sewer network and, on the other hand, that the impact of large-scale implementation of green and grey infrastructure could be maximized if they are located where excess runoff cannot be managed by RTC alone. More specifically, this paper aims at 1) describing how integrating rule-based RTC with green and grey infrastructure spatial optimization at the watershed scale has an impact on CSO frequency and volume reduction in comparison to their individual application, and 2) assessing how the cost necessary to reach specific CSO frequency targets could be reduced with the proposed RTC-green and grey infrastructure optimization framework.

\section{Methodology}

\subsection{Case study and modeling tool}

This research was conducted for a sub-area of the combined sewer network of a mediumsized municipality located in the Province of Quebec, Canada. The case study was modeled using PCSWMM (CHI, 2020). The sub-area totalizes 181 ha (divided in 44 sub-catchments), $15.2 \mathrm{~km}$ of pipes (diameters varying from $0.2 \mathrm{~m}$ to $1.5 \mathrm{~m}$ ) and 11 overflow structures with combined and pseudo-separated sewer sub-catchments (i.e. sub-catchments where only flat roofs are drained to the combined sewer pipes). The average imperviousness of the study area is $30 \%$, with individual sub-catchment imperviousness varying from 12 to $100 \%$. Some portions of the network have steep slopes (up to 8.5\%), whereas the interceptor is generally flat (with slopes varying from 0.1 to $2 \%$ ). Under current conditions, the network experiences severe and frequent overflows throughout the year. A description of the model calibration and validation process for the full network can be found in Jean et al. (2018). Even if the research was based on a sub-area of the entire municipality, inflows from the upstream part of the network were injected in the model upstream node to mimic the real catchment total inflows.

Static regulators are currently located downstream of 10 of the 11 overflow structures $(\mathrm{O}-$ 01 to O-10 in Fig. 1) to restrict the flowrate reaching the interceptor toward the wastewater treatment facility. The interceptor is fully saturated with upstream inflows. Therefore, this research considered increasing the capacity of the interceptor and regulators to represent future upgrades of the system. This modified state of the network was considered as the base case situation to ensure that the performance of the tested solutions in the study area is not affected by uncontrolled upstream inflows. From the 11 overflow structures distributed across the network, six are associated with CSO problems and were further analyzed.

In the Province of Quebec, CSO regulation is based on a maximal seasonal frequency from May to November. The provincial legislation for the 2040s horizon imposes a maximum of seven CSO spills per overflow structure and per season

This article is protected by copyright. All rights reserved. 


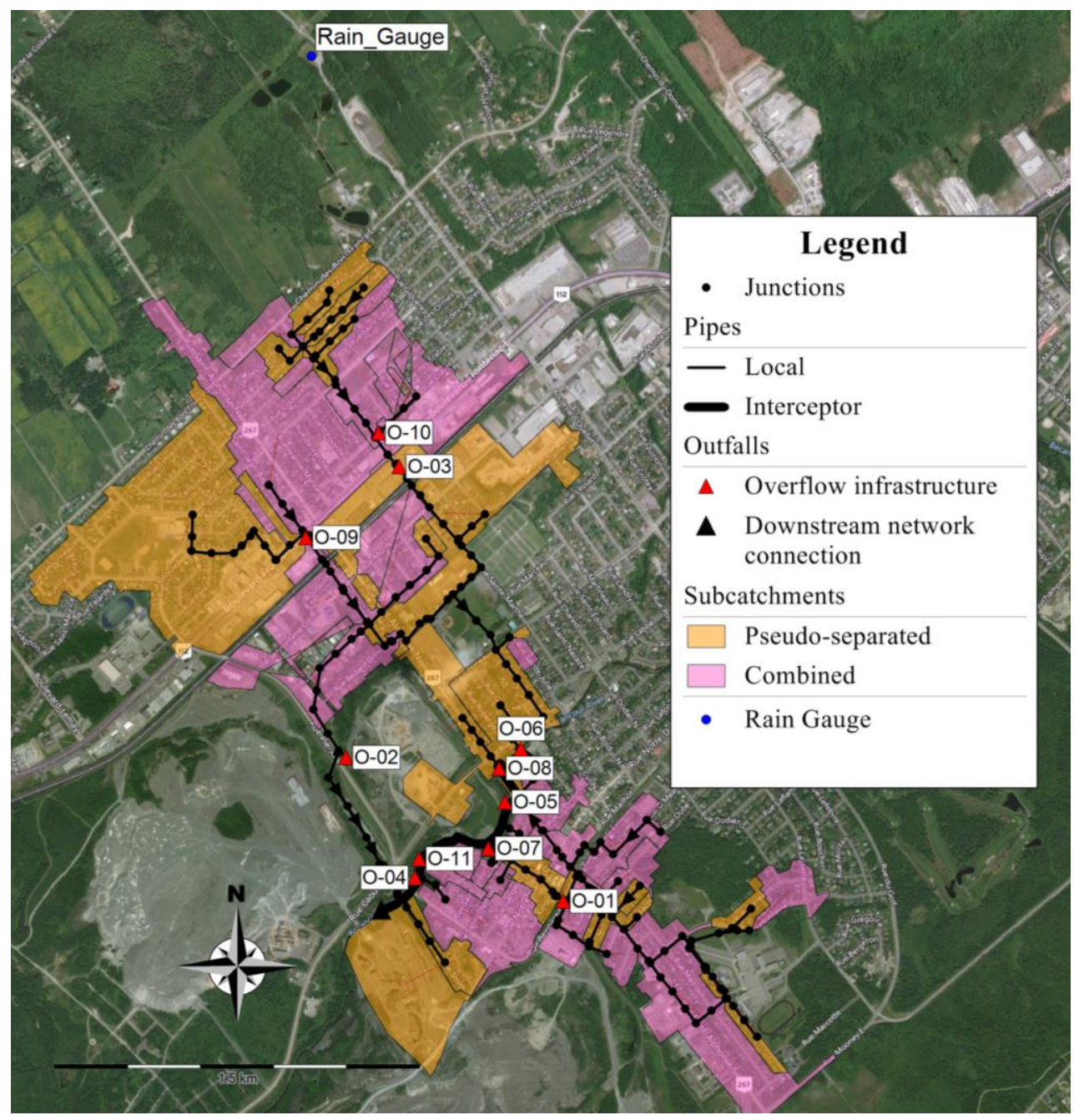

Figure 1. Case study sub-area. Note: the six overflow structures O-01 to O-06 are exceeding their CSO frequency limit

\subsection{Rainfall data}

\subsubsection{Historical rainfall data}

Continuous rainfall data recorded every 5 minutes over 9 years (2006-2009 and 20112015) were available from the municipal rain gauge station located less than $1 \mathrm{~km}$ north of the case study area. Only the wet weather months from May to November were simulated for CSO control as those are the months for which CSO maximal frequency targets are applicable in Quebec. Rainfall events are frequent, with seasonal rainfall depth ranging between 730 to 960 $\mathrm{mm}$. Through the selected years, maximal rainfall intensity over 5 minutes varied from 60 to 130 $\mathrm{mm} / \mathrm{h}$ and the average rainfall intensity per event from 3.5 to $5.2 \mathrm{~mm} / \mathrm{h}$. More details on the historical rainfall data set are available in Jean et al. (2018).

\subsubsection{Design rainfall events}

The optimization routine was first deployed for various scenarios using design rainfall events. The aim was to apply rainfall events that would correspond to the target CSO frequency 
(7 CSOs/season) as optimization design input. The different scenarios were afterwards submitted to continuous simulation of the available 9 seasons of rainfall data. Indeed, as demonstrated in Jean et al. (2018), it is not possible to determine one single rainfall event that would produce the same effect on all of the outfall structures in terms of CSO volume and frequency and, thus, continuous simulation is essential to refine the designs and validate their performance.

Two design rainfall events were used in the optimization process. The first design rainfall event is based on the synthetic Chicago rainfall distribution for high frequency intensityduration-frequency (IDF) curves and a return period of $1 /$ month (which is equivalent to the target frequency of 7 CSOs/season), as proposed in Jean et al. (2018). The second selected design rainfall event is a historical rainfall event that occurred on 30 July 2015. It was selected because it produced a CSO event volume approximately equal or above the maximum of the seventh largest annual CSO event volume among the nine years simulated for all the CSO outfalls, as determined from the continuous simulation of the base case scenario. Therefore, this historical event was considered to be representative of the target frequency of 7 CSO spills/season. The temporal distribution of the synthetic and historic rainfall events is shown in Fig. 2. It should be noted that the historical rainfall data are simulated using a 5 min interval, whereas the Chicago storm is based on 10 min interval. Both events have similar total duration (between 180 and 200 min) and total rainfall depth (between 20 and $25 \mathrm{~mm}$ ) but, as shown in Fig. 2, the Chicago storm has a much higher maximal intensity.

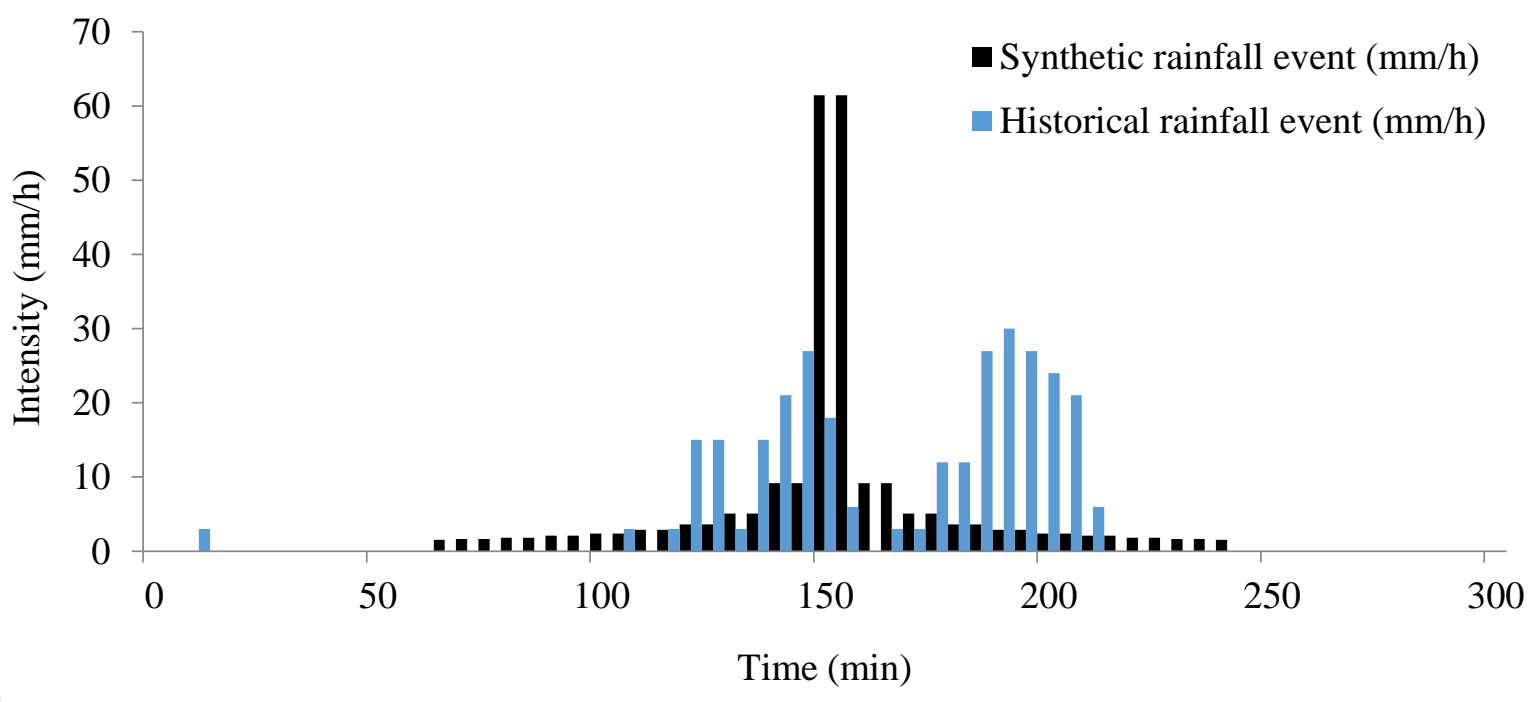

Figure 2. Design rainfall events temporal distribution

\subsection{Optimization framework}

The methodology relied on an optimization tool, called "Integrated Planning and Optimization Program" (iPOP). This software combines SWMM 5.1 (Rossman, 2015) for hydrological/hydraulic simulations and Parallel Swarm Oriented-Particle Swarm Optimization (PSO-PSO) for the optimization of any SWMM input parameter (such as LID design values, volume of storage units and control rules variables).

The workflow diagram of the optimization routine is shown in Fig. 3. Input data include the design rainfall event, described previously, and the penalty weights, cost functions and 
optimization objectives which are presented in section 2.4. In terms of processes, the optimization routine was completed in two steps, followed by a validation step. The $1^{s t}$ optimization step was conducted with iPOP to optimize, either jointly or separately depending on the assessed scenarios: i) the number and location of bioretention cells (i.e. GIs), ii) the number, location and volume of off-line storage tanks (i.e. grey infrastructures), and iii) the if-then-else rule parameters for partial closure and opening of gate settings at each RTC control point (i.e. replacement of the actual regulators by RTC sluice gates).

The $2^{\text {nd }}$ optimization step included two iterative loops. The first loop consisted of a manual adjustment of the gate setting parameters to complete the formulation of the RTC rules. The rules final setting of the gate opening state was conducted manually because they should not overlap the iPOP optimized values for the gate-closing state. The second iterative loop permits to adjust manually the total number of bioretention cells required to meet the optimization objectives. The procedure consisted of verifying if any bioretention cell could be withdrawn without exceeding the downstream capacity of the network or causing CSO volume when taking into account the complete optimized RTC operating rules.

Finally, as the optimization problem was solved for one of the two rainfall events, the solution was validated through continuous simulation of nine years (2006-2009 and 2011-2015) in SWMM (validation step). The RTC parameters optimized previously for a given scenario were kept unchanged during the validation step. For the scenarios involving grey infrastructure, a third iterative loop was conducted after validation to manually refine the total volume of the storage units to make sure that the CSO frequency target was achieved for each outfall with the lowest storage volume possible.

In the case of the scenarios integrating green and grey infrastructure with RTC, all the aforementioned steps in Fig. 3 were conducted except those steps outlined in blue, which were bypassed for the scenarios involving static management. Similarly, the steps identified in grey were omitted when no storage tanks were being implemented, and the steps identified in green were bypassed for scenarios which did not involve GI.

This article is protected by copyright. All rights reserved. 


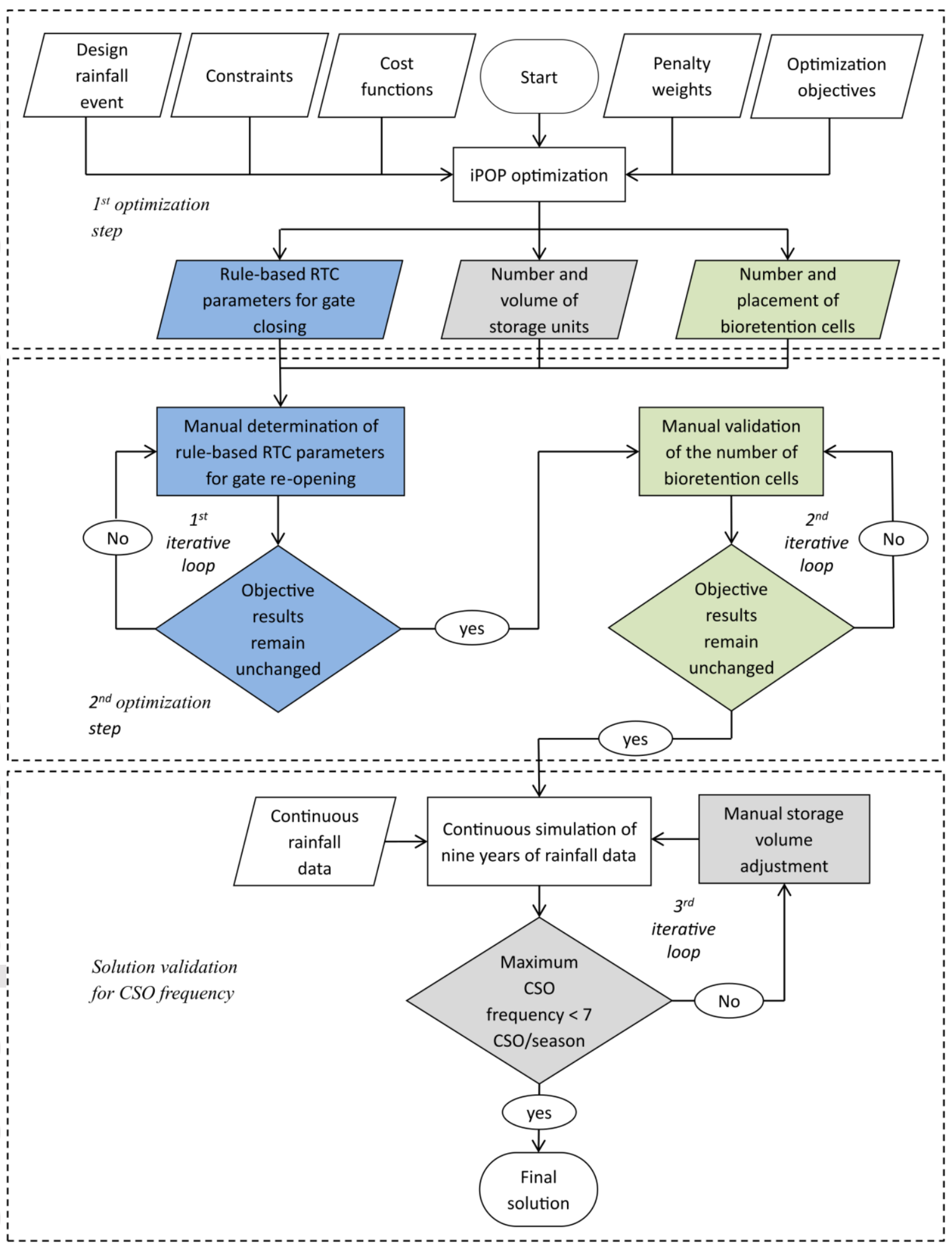

Figure 3. Optimization routine for integrating rule-based RTC with green and grey infrastructure design. Note: The blue steps were omitted when the optimization routine was applied to the static management scenarios and the grey and/or green cells were omitted when the scenarios did not involve grey or green solutions respectively.

This article is protected by copyright. All rights reserved. 


\subsection{Optimization problem}

The optimization problem consisted of defining the values of the following variables:

- Number of bioretention cells per sub-catchment $\left(\mathrm{BIO}_{\mathrm{SC}}\right)$

- Volume of potential underground off-line storage units $\left(\mathrm{VOL}_{\mathrm{s}}\right)$ upstream of each problematic outfall (O-01 to O-06 in Fig. 1)

- Rule-based RTC parameters for each of the potential nine control points (D1 $1_{\mathrm{CP}}, \mathrm{D} 2_{\mathrm{CP}}$, $\left.\mathrm{G} 1_{\mathrm{CP}}\right)$

The values of the optimization variables were defined to minimize the objective function presented below, while fulfilling the following constraints. The hydraulic constraints attached to the laws of conservation of mass and momentum are not detailed here as they are embedded in the SWMM model and can be found in Rossman (2015).

Objective function:

$$
\begin{gathered}
\sum_{S C=1}^{n_{S C}} B I O_{S C} \times \mathrm{B}_{B I O} \times \mathrm{A}_{B I O}+\sum_{S=1}^{n_{S T O}}\left(\mathrm{~A}_{S T O}+\operatorname{VOL}_{S} \times \mathrm{B}_{S T O}\right)+\sum_{i=1}^{n_{\text {outfall }}} W_{i} \times \max \left(0, \text { CSOvol }_{i}\right. \\
\left.- \text { Target }_{i}\right)+\sum_{D=1}^{n_{\text {Node }}} W_{D} \mathrm{x} \max \left(0, \text { SurDepth }_{D}-\text { Target }_{D}\right)+W_{F} \times \max \left(0, Q_{\text {cap }}\right. \\
\left.- \text { Target }_{F}\right)
\end{gathered}
$$

Constraints:

$$
\begin{gathered}
0 \leq B I O_{S C} \leq \text { BIOmax }_{S C} \forall l=1,2, \ldots, n_{S C} \\
0 \leq V O L_{S} \leq \operatorname{VOLmax}_{S} \forall S=1,2, \ldots, n_{S T O} \\
0 \leq D 1_{C P} \leq \operatorname{Diam}_{C P} \forall C P=1,2, \ldots, 9 \\
0 \leq D 2_{C P} \leq\left(D 1_{C P}-0.1\right) \forall C P=1,2, \ldots, 9 \\
F \operatorname{Fmin} \leq G 1_{C P} \leq 1 \forall C P=1,2, \ldots, 9
\end{gathered}
$$

Where:

$n_{S C}=$ Total number of combined sub-catchment (25 sub-catchments)

$B I O_{S C}=$ Number of bioretention cell units of $10 \mathrm{~m}^{2}$ for each sub-catchment $S C$

$\mathrm{B}_{B I O}=$ Capital cost per unit area of bioretention cell $\left(\mathrm{CAN} \$ / \mathrm{m}^{2}\right)=300 \mathrm{CAN} \$ / \mathrm{m}^{2}$ 
$A_{B I O}=$ Area occupied by one bioretention cell unit $\left(\mathrm{m}^{2}\right)=10 \mathrm{~m}^{2}$

$n_{\text {STO }}=$ Total number of storage units (varies from 0 to 6 )

$V O L_{S}=$ Volume for each storage unit $\left(\mathrm{m}^{3}\right)$

$A_{\text {STO }}=$ Minimal cost per storage unit (CAN \$) $(3,000,000$ CAN \$)

$\mathrm{B}_{\text {STO }}=$ Supplementaty capital cost per unitary stored volume $\left(\mathrm{CAN} \$ / \mathrm{m}^{3}\right)\left(600 \mathrm{CAN} \$ / \mathrm{m}^{3}\right)$

$n_{\text {outfall }}=$ Total number of outfall structures

$W_{i}=$ Cost weight factor associated to a given outfall infrastructure $i$ for one unit of CSOvol $_{i}$ above the Target $_{i}\left(50,000,000 \mathrm{CAN} \$ / \mathrm{m}^{3}\right)$

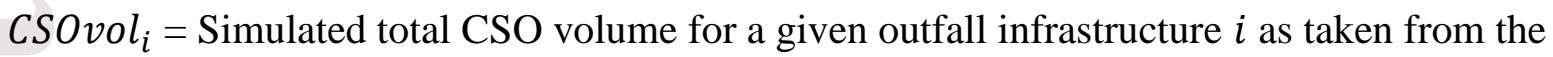
status report of $\operatorname{SWMM}\left(1,000 \mathrm{x} \mathrm{m}^{3}\right)$;

Target $_{i}=$ Target CSO volume associated with a given outfall structure $i\left(0 \times 10^{3} \mathrm{~m}^{3}\right)$

$n_{\text {Node }}=$ Total number of selected nodes to estimate network surcharges located downstream of each outfall structure (8 nodes)

$W_{D}=$ Cost weight factor associated to a given selected node $D$ for one unit of $S u r D e p t h_{D}$ above the $\operatorname{Target}_{D}(50,000,000 \mathrm{CAN} \$ / \mathrm{m})$

SurDepth $_{D}=$ Simulated maximal node depth value for a given selected node $D$ as taken from the status report of SWMM (m)

Target $_{D}=$ Target node depth associated with a given selected node $D$ to avoid excessive surcharge (m) (generally $0.15 \mathrm{~m}$ above the downstream crown height)

$\mathrm{W}_{\mathrm{F}}=$ Cost weighting factor associated to the downstream capacity of the network for one unit of $Q_{\text {cap }}$ above the $\operatorname{Target}_{F}\left(500,000,000 \mathrm{CAN} \$ \mathrm{~s} / \mathrm{m}^{3}\right)$

$Q_{c a p}=$ Simulated maximum downstream flowrate as taken in the status report of SWMM $\left(\mathrm{m}^{3} / \mathrm{s}\right)$ Target $_{F}=$ Target maximum flow corresponding to the network downstream capacity $\left(1 \mathrm{~m}^{3} / \mathrm{s}\right)$ $B I O \max _{S C}=$ Maximum number of bioretention cells of $10 \mathrm{~m}^{2}$ that can be implemented in each sub-catchment $S C$

VOLmax $=$ Maximum volume of underground storage units $S\left(\mathrm{~m}^{3}\right) C P=$ Potential control points for RTC implementation

$D 1_{C P}=$ Depth at the downstream confluence with the interceptor that will trigger the $C P$ gate partial closure

$D 2_{C P}=$ Depth at the downstream confluence with the interceptor that will trigger the $C P$ gate reopening

$\operatorname{Diam}_{C P}=$ Diameter of the pipe in which the water depth is measured in real-time for each $C P$ gate control

$G 1_{C P}=$ Fraction of opening at which the $C P$ gate should be maintained when the gates are partially closed

Fmin = Minimum gate opening fraction during its closing state (a value of 0.1 is applied)

This article is protected by copyright. All rights reserved. 
The objective function embedded in iPOP consisted of minimizing the sum of the total infrastructure costs for green and grey infrastructure and the system penalties associated with exceedance of three performance targets on i) CSO volume, ii) node surcharges, and iii) downstream network capacity. No RTC cost was directly applied through the optimization framework as an input parameter, because this cost was marginal compared to the other parameters. However, the calculated potential cost by each RTC control point was considered when evaluating the cost effectiveness of each scenario.

In terms of constraints, the feasible implementation range for bioretention cells detailed in Eq. 2 varied from zero to a maximal value determined for each sub-catchment either from the site suitability criteria map or the maximal impervious area that can be treated (see section 2.4.1 for more details). Regarding the storage volume bounds in Eq.3, the upper limit was set large enough to ensure the CSO control objective could be met. For rule-based RTC definition, the constraint defined by Eq. 4 aimed at avoiding network surcharges and/or exceeding the downstream capacity. The constraint represented by Eq. 5 ensures that the depth triggering the gate reopening is different enough from the depth triggering its closure so that the changes in gate states do not cause continuous oscillations between its closed and open positions. The last constraint (Eq. 6) aimed at avoiding the gates full closure, which could be a risk for the network upstream in case of gate malfunction.

More details about the variables, constraints, modeling choices and optimization algorithms are given in the following sections.

\subsubsection{Green infrastructure}

The spatial distribution of only one type of GI was optimized (i.e. bioretention cells) andto reduce the uncertainty associated with the selected GI scenarios, a sensitivity analysis of the bioretention cell costs and design input parameters was conducted.

Specific land suitability criteria were applied to define the upper implementation level limit of bioretention cells for each combined sewer sub-catchment based on design recommendations from the literature (see Supplementary Material). Spatial analysis was conducted by the Geographic Information System (GIS) software ArcGIS and data from orthophoto pictures, land use shape files and soil characterization map. Based on this analysis, the maximal available area for bioretention cells implementation and the maximal impervious area that could be potentially treated by bioretention cells were determined.

The loading ratio between the surface occupied by bioretention cells and the treated impervious surface was set equal to 1:10 (i.e. the bioretention cells can treat water from impervious areas totalizing 10 times their surface), which is a conservative value as recommended by CSA (2018) for the most contaminated runoff. Bioretention cells implementation was simulated on a per-unit basis using the LID control module of SWMM (Rossman et al., 2016). The parameters of the vertical layers constituting the bioretention cells design are specified in Table 1 and were primarily based on calibrated values from a previous monitoring study of GI implemented in the Province of Quebec (Bilodeau, 2018) and Canadian design guidelines for bioretention cells (CSA, 2018). The US EPA recommended values (Rossman et al., 2016) were applied for the remaining parameters (Table 1). Finally, the bioretention cells design values defined for the sensitivity analysis of the GI performance were based on the minimal and maximal design values reported in Table 1.

This article is protected by copyright. All rights reserved. 
Table 1. Bioretention Cells Design Parameters for SWMM LID Control Module

\begin{tabular}{|c|c|c|c|c|c|c|}
\hline \multirow[b]{2}{*}{ Layer } & \multirow[b]{2}{*}{ Parameter } & \\
\hline & & $\begin{array}{c}\text { Selected } \\
\text { design } \\
\text { value }\end{array}$ & $\begin{array}{c}\text { Canadian } \\
\text { guidelines } \\
(\mathrm{CSA}, 2018)^{\mathrm{a}}\end{array}$ & $\begin{array}{l}\text { EPA SWMM guidelines } \\
\text { (Rossman et al., 2016) }^{\text {b }}\end{array}$ & $\begin{array}{c}\text { Min }_{\text {LID }} \\
\text { value }^{c}\end{array}$ & $\begin{array}{c}\text { Max } \\
\text { LID } \\
\text { value }^{c}\end{array}$ \\
\hline \multirow{4}{*}{ Surface } & Berm height (mm) & 300 & $(300)$ & $150-300$ & 150 & 300 \\
\hline & $\begin{array}{l}\text { Vegetation volume } \\
\text { (fraction) }\end{array}$ & 0.1 & - & $0-0.2$ & 0.2 & 0.1 \\
\hline & Surface roughness ${ }^{b}$ & 0.3 & - & $0.03-0.2$ & 0.3 & 0.03 \\
\hline & Surface slope (\%) & 0.5 & - & $0.5-3$ & 0.5 & 3 \\
\hline \multirow{3}{*}{ S } & Thickness $(\mathrm{mm})^{b}$ & 450 & $>300(450)$ & $600-1200$ & 450 & 600 \\
\hline & Porosity (fraction) & 0.437 & - & $0.45-0.6(0.52)$ & 0.437 & 0.6 \\
\hline & $\begin{array}{l}\text { Field capacity } \\
\text { (fraction) }^{\mathrm{b}}\end{array}$ & 0.105 & - & $0.15-0.25(0.15)$ & 0.105 & 0.25 \\
\hline \multirow[t]{4}{*}{ Soil } & $\begin{array}{l}\text { Wilting point } \\
\text { (fraction) }^{\mathrm{b}}\end{array}$ & 0.047 & - & $0.05-0.15(0.08)$ & 0.047 & $0.047^{\mathrm{d}}$ \\
\hline & Conductivity $(\mathrm{mm} / \mathrm{h})$ & 140 & - & $50-140(120)$ & 50 & 140 \\
\hline & $\begin{array}{l}\text { Conductivity slope } \\
(\%)\end{array}$ & 30 & - & $30-55(40)$ & 30 & 55 \\
\hline & Suction head $(\mathrm{mm})^{\mathrm{b}}$ & 110 & - & $50-100(50)$ & 110 & 50 \\
\hline \multirow{4}{*}{ Storage } & Thickness (mm) & 600 & $>300(600)$ & $150-900$ & 300 & 900 \\
\hline & Void ratio (fraction) ${ }^{b}$ & 0.5 & - & $0.2-0.4$ & 0.2 & 0.5 \\
\hline & Seepage rate $(\mathrm{mm} / \mathrm{h})$ & 5 & - & - & 5 & 15 \\
\hline & $\begin{array}{l}\text { Clogging factor } \\
\text { (fraction) }\end{array}$ & 0 & - & - & 400 & 0 \\
\hline
\end{tabular}

${ }^{a}$ The values in parentheses correspond to the recommended value if applicable.

${ }^{b}$ Values slightly outside the EPA SWMM range guidelines were based on calibrated values (Bilodeau, 2018).

${ }^{\mathbf{c}}$ The minimal and maximal design values represent the values leading to a net decrease or increase in the LID CSO reduction performance, respectively.

d The best CSO reduction performance is obtained for a greater difference between the wilting point and the field capacity fractions, which explains why only the field capacity fraction is increased for the Max LID value case.

\subsubsection{Real-time control implementation}

The rule-based RTC strategy was implemented for potentially nine control points (overflow infrastructure O-01 to O-09 on Fig. 1). The most upstream regulator (located beside the outfall O-10) was not included in the analysis as it drains only a small portion of the network. The optimization scheme also permitted optimizing the total number of RTC control points by evaluating if applying a dynamic control on all gates or only on some of them provides similar benefits.

\subsubsection{Cost evaluation}

The bioretention cells cost calculations embedded in the objective function was simplified as a linear function of the bioretention cells implementation area. The cost values applied were based on an estimation of the construction cost considering the bioretention vertical layers design recommendations of the literature presented in Table 1 and material and

This article is protected by copyright. All rights reserved. 
construction costs encountered in the Province of Quebec. A cost estimation of 300 CAD \$ $/ \mathrm{m}^{2}$ was calculated, which corresponds with the mid-range value of various bioretention cells projects led in the Province of Quebec (costs varying from 150 to 400 CAD $\$ / \mathrm{m}^{2}$ reported by Bilodeau, 2018).

Similarly, values applied for storage units cost evaluation were based on three previous construction projects realized in other sub-catchment areas of the case study. The reported projects correspond to concrete underground storage tanks of various sizes with gravitational outflow and self-cleaning mechanism (personal communication with Bilodeau, 2020). Based on this information, an initial investment of about 3,000,000 CAD \$ was considered necessary for grey infrastructure implementation in addition to a per-volume cost of $600 \mathrm{CAD} \$ / \mathrm{m}^{3}$.

Finally, the RTC implementation cost, which is the investment cost required to replace each static regulator with a moveable gate and RTC technology, was determined based on costs applicable to the Province of Quebec, which are approximately 1,150,000 CAD\$ per site (personal communication with Lussier, 2021).

More details on the cost data are presented in the Supplementary Material section.

\subsubsection{Optimization algorithm}

The optimization tool (iPOP) was applied to solve the optimization problem using the Parallel Swarm Oriented-Particle Swarm Optimization (PSO-PSO). The PSO-PSO algorithm is an evolutionary population-based search algorithm where a series of solution candidates (i.e. particles), are evolving at each iteration (i.e. generation). When applying PSO-PSO, the population is further divided in parallel sub-swarms, each grouping an equal number of particles. Therefore, the algorithm takes into account the sub-swarm best solution in addition to the particles and population best solutions (Gonsalves \& Egashira, 2013). The equations of the PSOPSO algorithm are given in the Supplementary Material section.

The number of particles per generation, the number of sub-swarms and the total number of generations are user-specific parameters of iPOP. For this research, four swarms of 50 particles and 60 generations were simulated, for a total of 12000 particles $(1$ particle $=1$ design alternative) per scenario assessed. At each generation, iPOP modifies the input file of a SWMM reference scenario to produce different SWMM input files, each corresponding to one PSO particle. By applying the PSO-PSO algorithm, iPOP should converge toward an "optimal" or "near-optimal" SWMM input file which corresponds to a specific design alternative in terms of GI distribution and/or storage volume and/or RTC rule-based definition.

\subsection{Scenarios}

The scenarios compared can be differentiated according to the design rainfall event used in the optimization process and the three potential types of design outputs optimized: 1) the rules parameters for RTC gates, 2) the number and spatial distribution of GI, and 3) the spatial distribution and volume of grey infrastructure. Table 2 provides a summary of all scenarios compared when all permutations of these design parameters were considered.

Table 2. Description of the Scenarios

$\begin{array}{lllll}\text { Scenario name } & \text { Type of } & \text { Green } & \text { Grey } & \text { Design }\end{array}$

This article is protected by copyright. All rights reserved. 


\begin{tabular}{|c|c|c|c|c|}
\hline & control & infrastructure & infrastructure & rainfall event \\
\hline 1. Base case & Static & - & - & N/A \\
\hline 2A. RTC- Chicago & RTC & - & - & Chicago \\
\hline 2B. RTC- July & RTC & - & - & 30 July 2015 \\
\hline 3. GreyDesign ${ }^{1}$ & Static & - & $\mathrm{X}$ & N/A \\
\hline 4A. RTC-Grey- Chicago & RTC & - & $\mathrm{X}$ & Chicago \\
\hline 4B. RTC-Grey-July & RTC & - & $X$ & $30^{\text {th }}$ July 2015 \\
\hline 5A. GreyGreen- Chicago & Static & $X$ & $\mathrm{X}$ & Chicago \\
\hline 5B. GreyGreen-July & Static & $\mathrm{X}$ & $\mathrm{X}$ & 30 July 2015 \\
\hline 6A. RTC-GreyGreen- Chicago & RTC & $\mathrm{X}$ & $\mathrm{X}$ & Chicago \\
\hline 6B. RTC-GreyGreen-July & RTC & $\mathrm{X}$ & $\mathrm{X}$ & 30 July 2015 \\
\hline 7A. Green- Chicago & Static & $\mathrm{X}$ & - & Chicago \\
\hline 7B. Green-July & Static & $\mathrm{X}$ & - & 30 July 2015 \\
\hline 8A. RTC-Green- Chicago & RTC & $\mathrm{X}$ & - & Chicago \\
\hline 8B. RTC-Green-July & RTC & $\mathrm{X}$ & - & 30 July 2015 \\
\hline
\end{tabular}

\section{Results and discussion}

\subsection{Scenarios performance}

Table 3 presents the optimization results for each scenario in terms of cost, infrastructure designs and CSO performance by indicating the number of outfalls for which the maximum allowable CSO frequency target of $7 \mathrm{CSO} /$ season was exceeded. As shown, the CSO frequency objective cannot be achieved without the construction of grey infrastructure, but the integration of GI and RTC permit to significantly reduce the costs of the designed solutions. From all the scenarios studied, the scenario 6A, integrating green and grey infrastructures with RTC, is the one that achieves the objectives at the lowest cost.

Indeed, whereas the scenarios involving RTC alone were the cheapest solutions, they could not reach the CSO frequency targets for 6 problematic outfalls. In contrast, the addition of grey infrastructure was an effective solution under both static and RTC management and required similar investment costs (between approximately 23 to 24 million CAD\$). Also, the total design storage volume could be reduced considerably by RTC.

Moreover, all the solution alternatives involving static control and grey infrastructure alone or in integration with GI (scenarios 3, 5A and 5B) reached the design objectives with similar investment costs (about 24 million CAD\$), while static control combined with GI alone (7A and 7B) required half the investment costs, but failed to achieve CSO target goals at four outfalls. The upper limit on the maximum number of bioretention cells that could be implemented was reached for almost all the sub-catchments in scenario 7A, but it was not sufficient to reduce the CSO occurrence below an acceptable level. On the contrary, if the option of implementing RTC was applied in integration with GI or with a mix of green-grey infrastructure using the Chicago storm (scenarios $6 \mathrm{~A}$ or $8 \mathrm{~A}$ ), the total solution cost remained among the lowest (12.5 to 15.2 million of CAD\$, respectively) and still achieved the CSO frequency target or nearly so (in scenario 8A, only outfall O-06 exceeded its CSO frequency target, during one year). Interestingly, this means that the cost for upgrading the network to reach

This article is protected by copyright. All rights reserved. 
its CSO frequency objective under static control remained approximately the same for scenarios involving grey infrastructure even if GI was integrated in the design process, because the statically controlled regulators have a fixed capacity, and any water in excess must be either captured upstream with GIs or off-line with grey infrastructure. In contrast, optimizing RTC and GI (with or without grey infrastructure) permits to control both the surface runoff and the flowrate within the network; providing the highest flexibility for CSO reduction and potential cost savings. Therefore, for the case study assessed, RTC benefits are mostly obtained when distributed GIs are integrated in the design solution, because this type of infrastructure can be implemented where RTC is less effective, and because this solution is cheaper to implement than centralized underground storage units.

Differences in performance results between the solutions optimized with the synthetic event (scenarios A) and historical event (scenarios B) is often marginal but, in general, optimization with the synthetic event is slightly more effective in terms of maintaining the CSO target limits for all outfalls and all years. For instance, scenarios involving RTC and green and grey infrastructure optimized under the Chicago storm (6A) did respect the CSO frequency objective as opposed to the same scenario optimized under the historical event (6B), which exceeded the maximal CSO occurrence for two outfalls (see Table 3). The exceedance occurs only during one simulated year, and could be easily avoided by integrating more bioretention cell units (i.e. 2.25 ha such as optimized for the scenario 6A instead of 1.86 ha for the scenario 6B). Therefore, only the optimization results obtained with the synthetic rainfall event are further detailed here while the remaining results obtained with the historical event are presented in the Supplementary Material section.

This article is protected by copyright. All rights reserved. 
Table 3. Optimized Solutions Costs, Infrastructure and Performance

\begin{tabular}{lccccc} 
Scenarios & \$ CAD & $\begin{array}{c}\text { Total } \\
\text { storage } \\
\text { volume } \\
\left(\mathbf{m}^{\mathbf{3}}\right)\end{array}$ & $\begin{array}{c}\text { Total } \\
\text { bioretention } \\
\text { area } \\
\text { (ha) }\end{array}$ & $\begin{array}{c}\text { Number } \\
\text { of RTC } \\
\text { gates }\end{array}$ & $\begin{array}{c}\text { Number of } \\
\text { outfalls with } \\
\text { CSO frequency } \\
\text { > target }\end{array}$ \\
\hline 1. Base case & 0 & - & - & - & 6 \\
2A. RTC- Chicago & $1,150,000$ & - & - & 9 & 6 \\
2B. RTC- July & $1,150,000$ & - & - & 9 & 6 \\
3. Grey-Design & $23,940,000$ & 9,900 & - & - & 0 \\
4A. RTC-Grey- Chicago & $23,075,000$ & 7,500 & - & 5 & 0 \\
4B. RTC-Grey-July & $22,530,000$ & 6,400 & - & 6 & 0 \\
5A. GreyGreen- Chicago & $24,075,000$ & 6,300 & 1.77 & - & 0 \\
5B. GreyGreen-July & $23,625,000$ & 6,600 & 1.56 & - & 0 \\
6A. RTC-GreyGreen- Chicago & $15,220,000$ & 2,800 & 2.25 & 7 & 0 \\
6B. RTC-GreyGreen-July & $13,820,000$ & 2,200 & 1.86 & 8 & 2 \\
7A. Green- Chicago & $12,060,000$ & - & 4.02 & - & 4 \\
7B. Green-July & $11,880,000$ & - & 3.96 & - & 4 \\
8A. RTC-Green- Chicago ${ }^{1}$ & $12,545,000$ & - & 3.99 & 5 & 1 \\
8B. RTC-Green-July & $11,855,000$ & - & 3.76 & 5 & 2 \\
\hline
\end{tabular}

${ }^{1}$ For scenario 8A, nine CSOs were simulated in 2011 for outfall O-06, but volumes of the two smallest CSO events exceeding the limit remained relatively small (<11 and $5 \mathrm{~m}^{3}$ respectively).

The total CSO volume simulated for the entire study area and the maximal seasonal CSO frequency reached for each problematic outfall during the nine simulated years are presented in Fig. 4 and Fig. 5, respectively.

In general, scenarios in which RTC and/or GI are implemented improve CSO volume and frequency reduction such as expected according to previous literature reported in the introduction. More specifically, whereas the scenario involving RTC alone (2A) exceeds the maximal allowable CSO frequency limit, it can still reduce by $40 \%$ the total CSO volume compared to the base case scenario. GI can further reduce CSO volume by up to $98 \%$ when this green alternative is implemented with RTC (8A) or by about $95 \%$ when a mix of green and grey infrastructures are integrated with RTC (6A). Under static control of the network, the amount of CSO volume reduction is still considerable when GI is implemented, with a CSO reduction of about $89 \%$ for the scenario involving GI alone (7A) and about $93 \%$ in the case of the scenario mixing green and grey infrastructures (5A). However, Fig. 5 shows that for three outfalls, scenario 7A results in high CSO frequency as the maximal CSO frequency simulated at these locations is between 50 to 60 events per season. This poor performance is explained by the constraint on the maximal number of bioretention cells that can be implemented, according to the spatial analysis, and the restrictive flow rate that can pass through the static regulators. Stovin et al. (2013) also found that GI alone was not sufficient to cope with CSO problems in all the subcatchments analyzed. In contrast, the scenario integrating RTC and GI without grey infrastructure (8A) is able to maintain a frequency of seven spills per year for almost all outfalls as the RTC management offers more flexibility than the static regulators where GI space availability is more restrictive.

This article is protected by copyright. All rights reserved. 
These results demonstrate that the scenarios involving a mix of green and grey infrastructures are generally more robust in maintaining the maximal allowable CSO frequency targets for similar CSO volume reduction and that their integration with RTC permits to further reduce the investment cost. Results obtained by Altobelli et al. (2020) for a combined sewer system submitted to similar climatic conditions in northern Italy suggested that RTC alone or in combination with either green or grey infrastructures can contribute to reducing CSO volume compared to scenarios involving only a static control of the system, and that grey infrastructure is still necessary for eliminating CSO occurrence. In the same vein, Lucas and Sample (2015) conducted a study for a small combined sewer catchment in Virginia, USA, and found that GI combined with RTC tend to reduce the CSO volume by a greater amount as compared to grey infrastructures, while the latter perform better in terms of reducing CSO frequency.

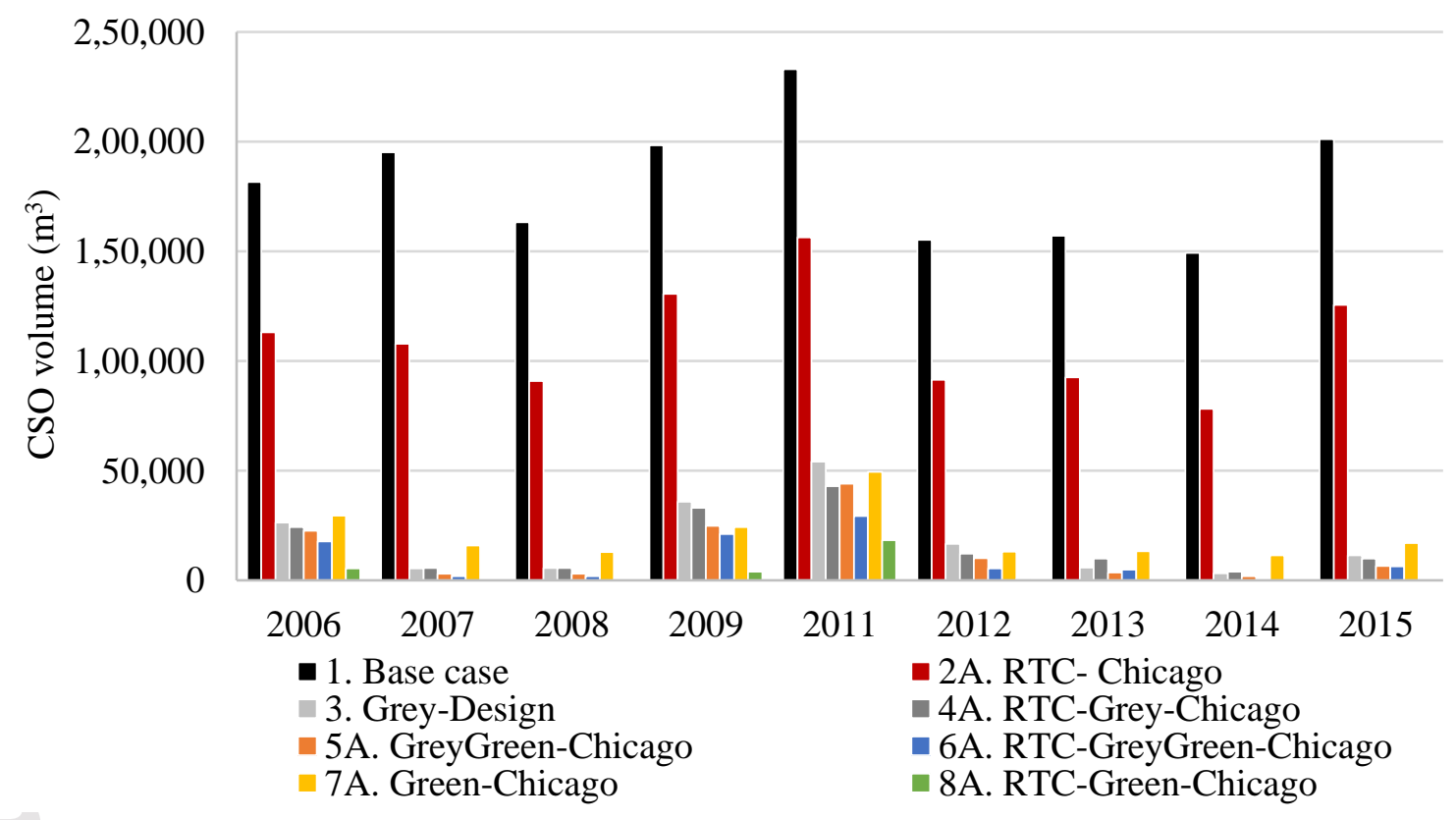

Figure 4. Total CSO volume for all optimized scenarios

This article is protected by copyright. All rights reserved. 
100

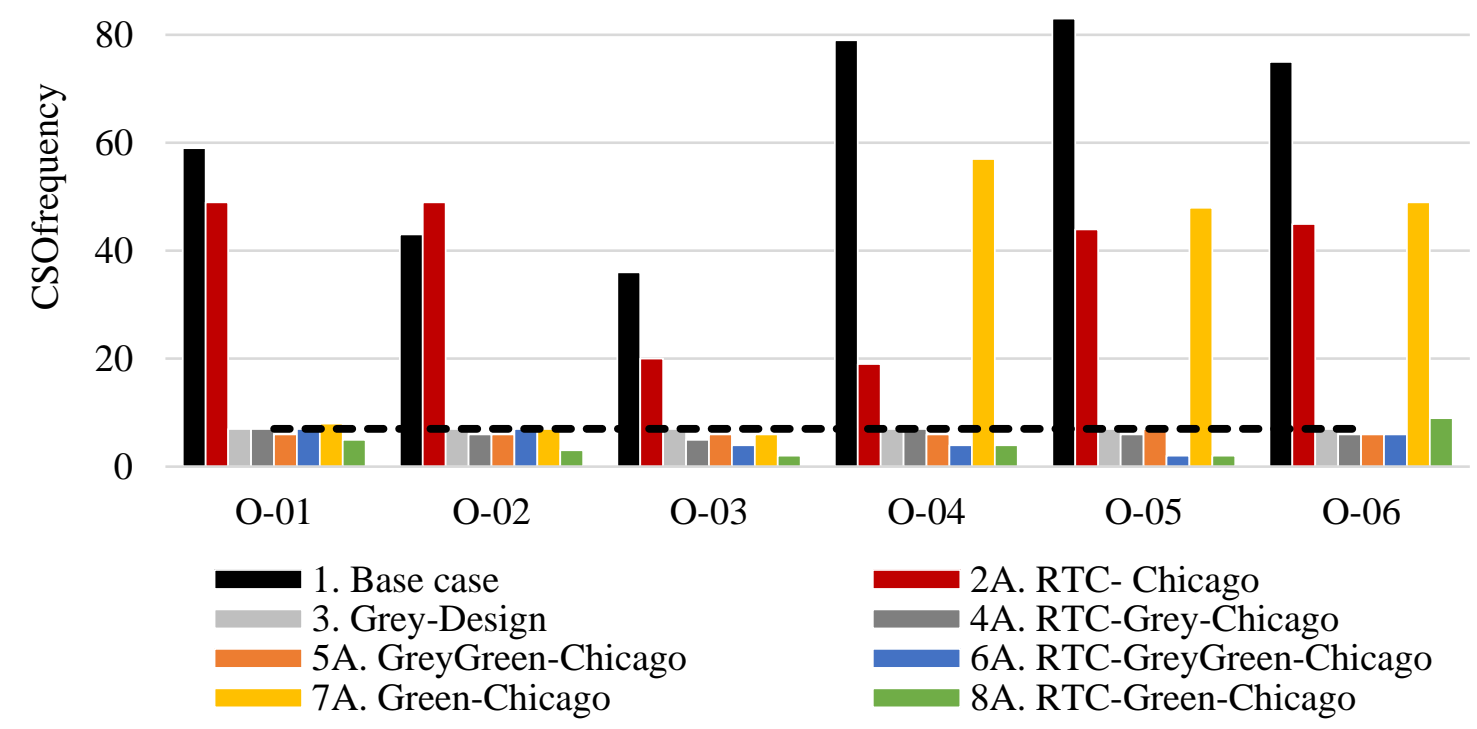

Figure 5. Maximal seasonal CSO frequency reached per outfall for all 9 simulated years. Note: The dashed line represents the seasonal CSO frequency limit of 7 CSOs/season

\subsection{Cost-benefit analysis}

The cost-benefit ratio of the mean CSO volume reduction (i.e. the total scenario cost divided by the difference in simulated mean seasonal CSO volume between the base case scenario and the assessed scenario) was calculated for each scenario optimized under the synthetic rainfall event and for which the maximal CSO target frequency was not exceeded, as well as for scenario 8A (one exceedance). Therefore, results for a total of five scenarios are presented in Fig. 6.

The uncertainty attached to the estimated grey and green infrastructures cost is illustrated through error bars representative of a variation in the storage and bioretention cells costs of \pm $50 \%$. A greater cost uncertainty is attached to scenarios having a greater total volume of grey infrastructure as this type of solution is, on average, more costly than GI. The scenario integrating RTC and GI (8A) remains the most cost-effective solution considering cost uncertainties (the cost of scenario $8 \mathrm{~A}$ is about $70 \$ / \mathrm{m}^{3}$ of average seasonal CSO volume reduction compared to about $90-150 \$ / \mathrm{m}^{3}$ for the remaining scenarios). This scenario, however, requires a high number of bioretention cells to reach the CSO frequency target, with the upper limit on the number of bioretention cells reached in almost all sub-catchments, as compared to the scenario integrating RTC with both green and grey infrastructure (6A), which requires about half the bioretention cells. As compared to scenario 8A, scenario 6A might be more readily applicable and practical due to its more modest implementation of bioretention cells; it is also one of the most cost-effective alternatives. Alves et al. (2016) also found that combining green and grey infrastructures was the most cost-effective solution for CSO abatement as centralized storage units can be implemented where space availability limits GI implementation.

As a comparison, the analysis of Montalto et al. (2007) suggested that for high GI cost, storage tanks become a more cost-effective solution for CSO abatement, but as GI cost decrease,

This article is protected by copyright. All rights reserved. 
the opposite effect is obtained. The study of Joshi et al. (2020) also suggests important cost reduction when GIs are implemented rather than grey infrastructures. In our case, the scenarios integrating RTC with GI, with or without storage units, are always more cost-effective than any other option that does not include GI, even considering a high cost variation. Similarly to what we obtained, Frey et al. (2013) suggested that a combination of RTC and green and grey infrastructures permits important cost savings. Other studies which did not include RTC in their analysis concluded that mixing green and grey infrastructures is the best option for balancing the network performance and cost (Dong et al., 2017; Liao et al., 2015; Tavakol-Davani et al., 2015).

a)

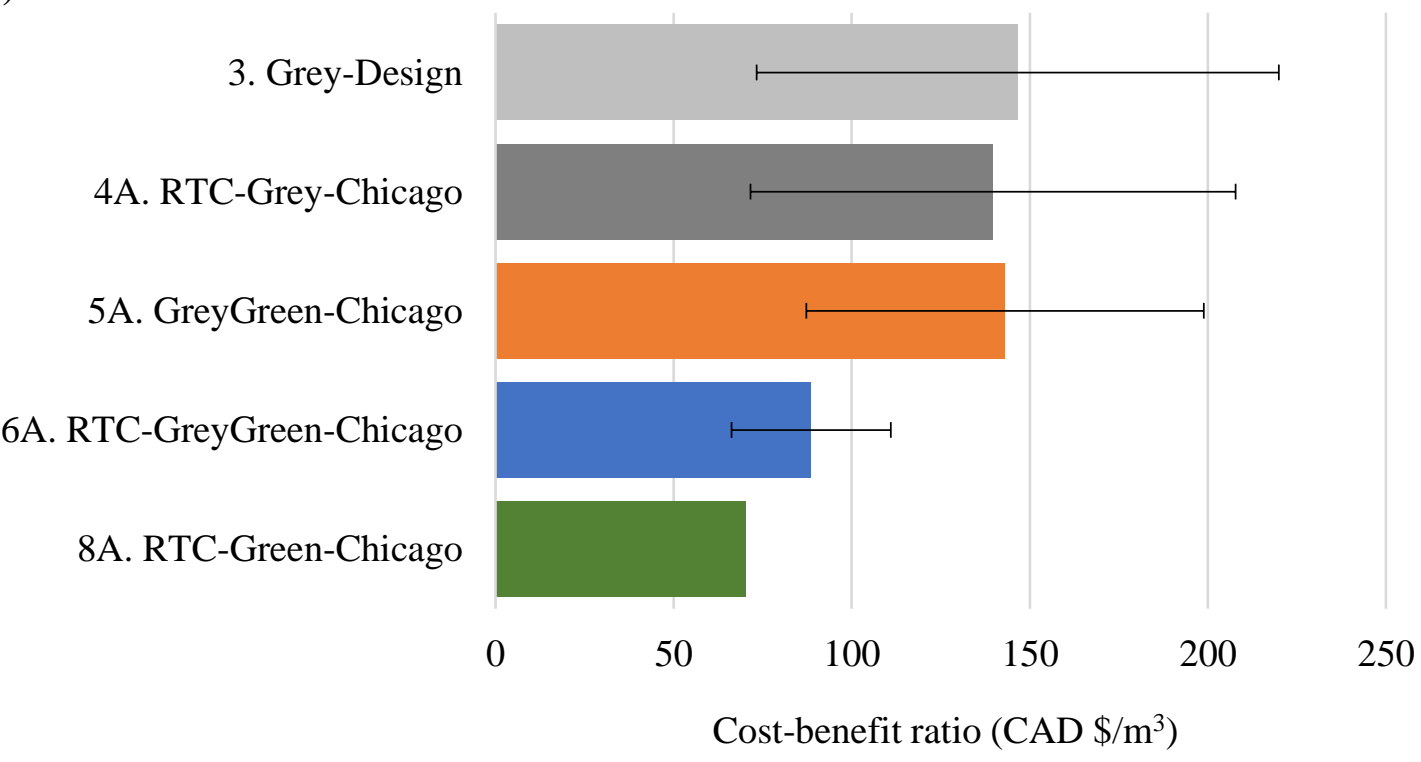

b)

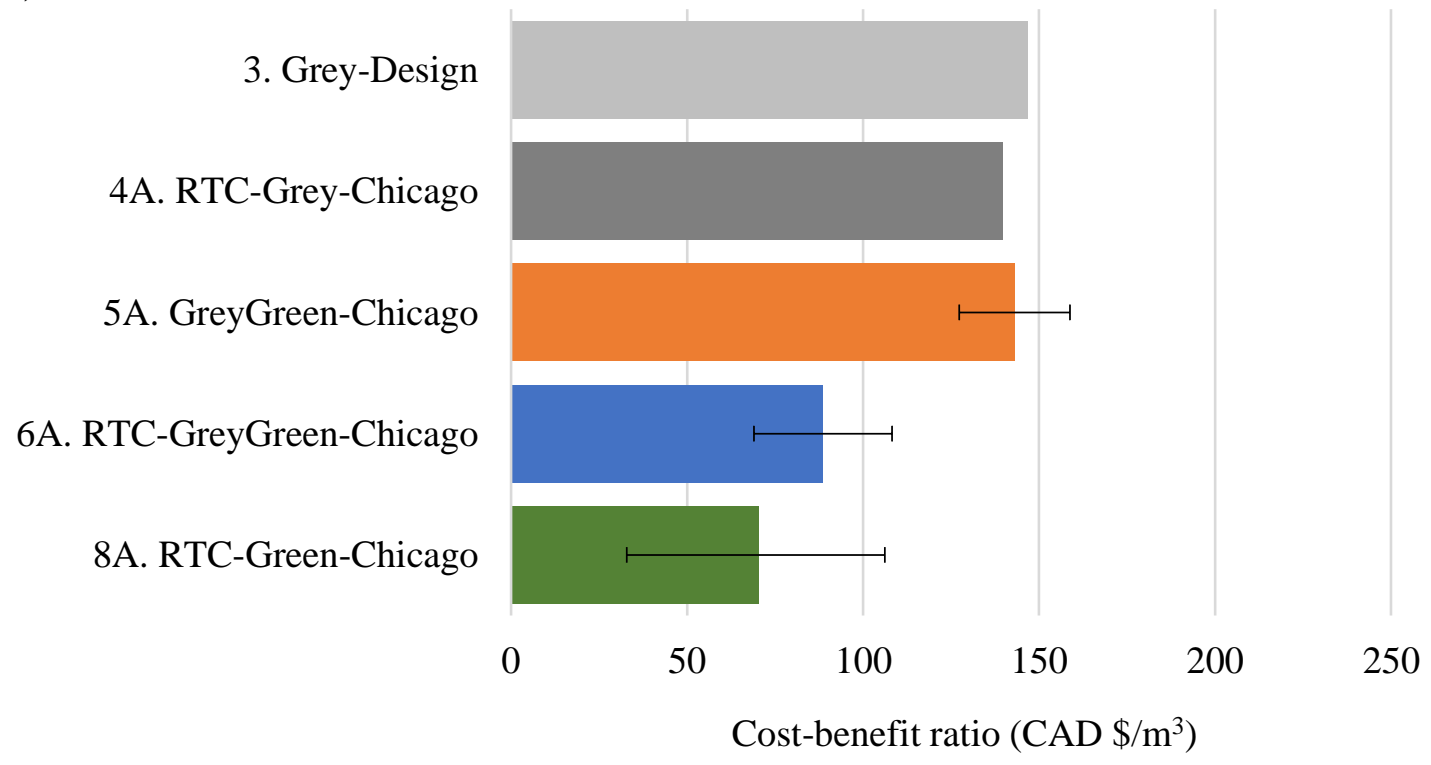

Figure 6. Cost-benefit ratio for selected scenarios: a) Cost-benefit ratio for storage price variation of $\pm 50 \%$; b) Cost-benefit ratio for bioretention cells price variation of $\pm 50 \%$. 


\subsection{Sensitivity analysis of GI design}

GI design parameters sensitivity was assessed for scenarios based on the Chicago rainfall event combining green and grey infrastructures with RTC (6A) and integrating RTC with GI (8A), as they present the best cost-benefit ratios. The two scenarios were simulated for the nine years of available continuous rainfall data for four different sets of LID input parameters in SWMM, without changing their optimized RTC rules, the bioretention cells spatial distribution nor their storage units volume (in the case of scenario 6A). More specifically, the LID design parameters were changed for the minimal and maximal design values listed in Table 1 (scenarios LID-MIN and LID-MAX respectively), and for a LID loading ratio increased to 1:15 and 1:20.

As shown in Fig.7, the maximal CSO frequency reached over the continuous simulation period for each outfall was not necessarily increased or decreased by the changes in the LID input parameters, particularly in the case of scenario 6A. The storage units provided additional runoff capture when the bioretention cells became more rapidly saturated due to either decreased design performance or increased loading ratio. Scenarios are less sensitive to an increase in GI performance as bioretention cells are saturated only for a few larger rainfall events and those rainfall events are, for the most part, the same ones as those responsible for the CSOs occurring in the original scenario. Moreover, Fig. 7 indicates that a ratio of 1:20 is not sustainable for the two analyzed scenarios, but that a ratio of 1:15 or lower LID design values are still acceptable when grey infrastructure is integrated with GI and RTC, as opposed to the scenario involving only GI and RTC. Similarly, Lewellyn et al. (2018) found that GI performances were not impacted by back-to-back rainfall events if the native soil conductivity was sufficiently high. Indeed, under appropriate design and implementation site selection, GIs are likely to provide sufficient runoff capture under a variety of rainfall events.

According to the presented results, integrating the optimization of green and grey infrastructures with RTC might present a safer option to achieve high CSO volume and CSO frequency reductions even under GI performance uncertainty.

This article is protected by copyright. All rights reserved. 
a)

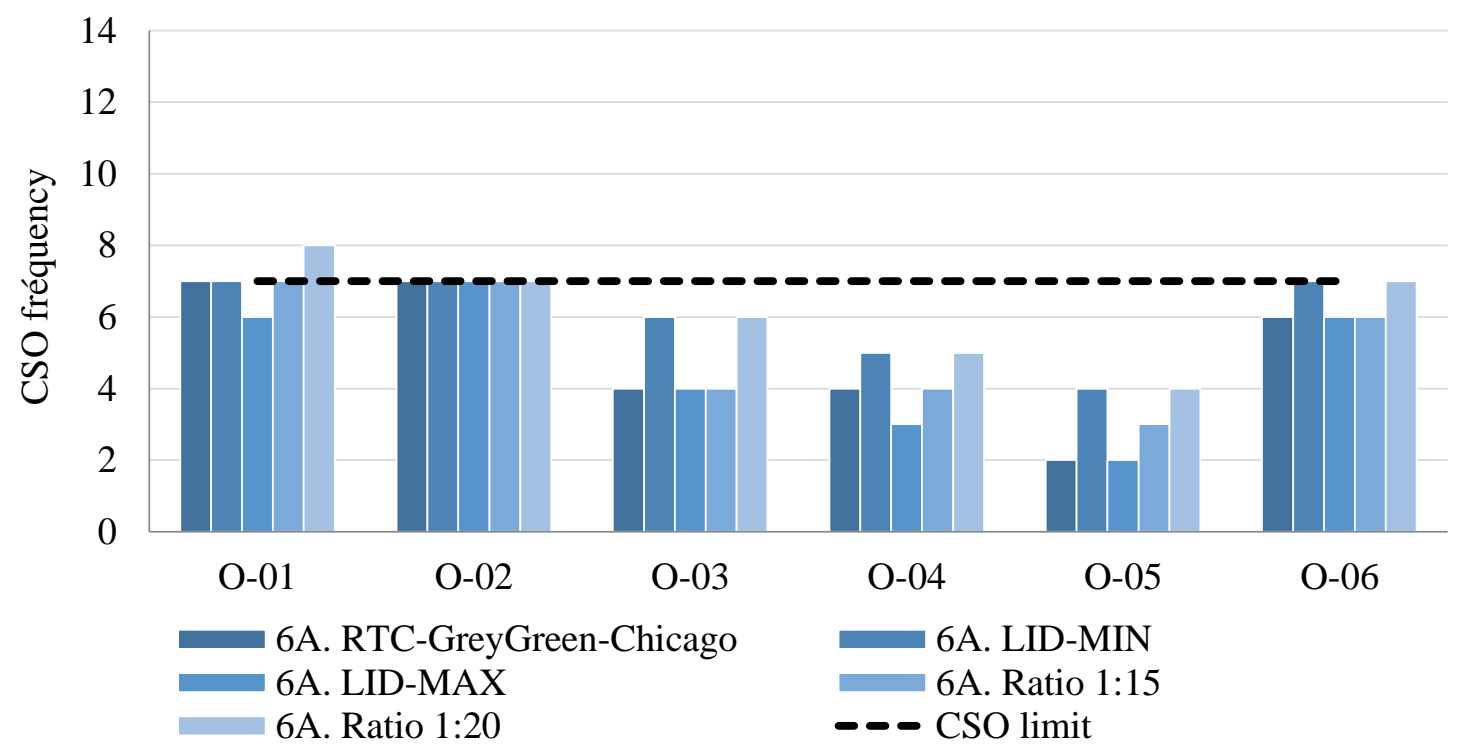

b)

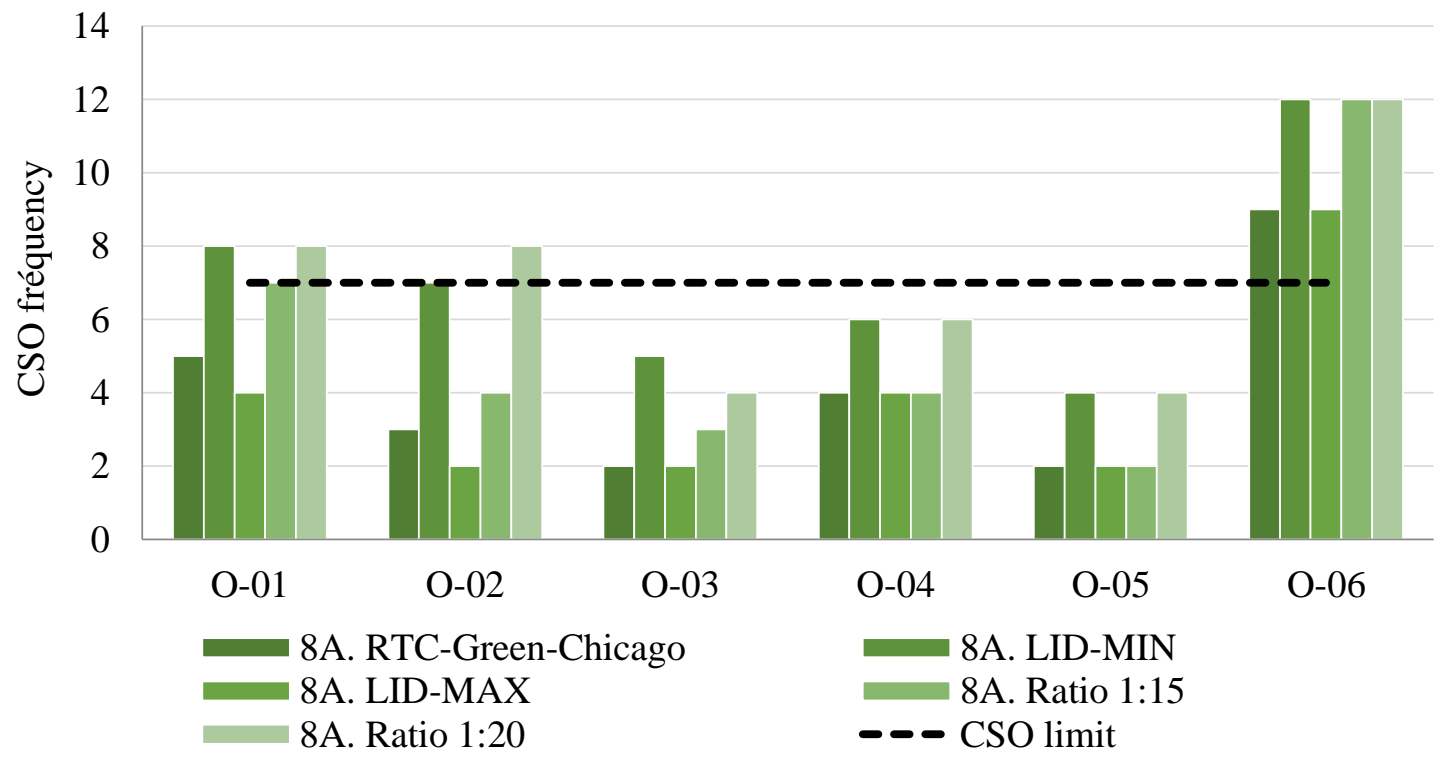

Figure 7. GI design sensitivity on maximal annual CSO frequency per outfall: a) 6A. RTCGreyGreen-Chicago scenario; b) 8A. RTC-Green-Chicago scenario. Note: The dashed line represents the seasonal CSO frequency limit of $7 \mathrm{CSO} /$ season

\section{Conclusions}

CSO regulations are requiring municipal actions toward implementing cost-effective solutions for combined sewer network upgrades. This study aimed at orienting the design of those solutions through an innovative optimization framework. Results demonstrated that:

This article is protected by copyright. All rights reserved. 
- Under static control of the network, the total cost to reach CSO frequency targets:

- remains similar for solutions integrating grey infrastructure alone or in combination with GI;

o is higher than the cost of solutions involving RTC.

- Spatial optimization of GI with RTC leads to maximal CSO volume reduction at the lowest investment cost, as compared to static control or traditional combination of RTC and grey infrastructure, however, it:

- requires a high number of GI everywhere in the catchment area;

- results in a CSO frequency that is more sensitive to a variation in GI design parameters as compared to the scenario integrating RTC with green and grey infrastructure.

- Integration of the optimization of a mix of green and grey infrastructure with RTC presents the safest option for CSO control, as it:

○ provides one of the most cost-effective solutions;

$\circ$ ensures robustness under varying GI design parameters and solution design costs.

This study contributes to improve the development of CSO control solutions that are potentially more affordable, efficient, and adaptable to a variety of networks, rainfall conditions, and CSO control objectives. The applied methodology could easily be reproduced by adapting the optimization parameters according to any combined sewer context.

Future research work should assess the impact of GI design for CSO abatement of more complex RTC schemes, such as model predictive control, to evaluate if additional benefits could be obtained from a more optimal control of network flowrates. Moreover, the impact of integrating both RTC applications (within the network and on distributed GIs on site) should be assessed in terms of CSO performance objectives. A better understanding of the impact of largescale implementation of GI on CSO frequency and volume could improve the design of such novel solutions for combined sewer networks. Finally, the optimization framework should be applied for various case studies and climatic data to evaluate the potential benefits and robustness of combining RTC with green and grey infrastructure under a variety of conditions.

This article is protected by copyright. All rights reserved. 


\section{Acknowledgments, Samples, and Data}

- This research was funded by Grant RDCPJ 487284-15 and Grant ALLRP 544594-19 from Natural Sciences and Engineering Research Council of Canada. The graduate studies of M-È Jean are supported by the Vanier Canada Graduate Scholarship from the Government of Canada.

- The authors are particularly grateful for the technical support of Jamie M. Brescol, Karine Bilodeau, Christiane Marcoux and Leni Trudel at Tetra Tech CSO, of the chief of Engineering and Environment of the selected case-study municipality and of Véronique Guay from INRSETE. Their contributions helped to develop the case study model and optimization scheme. Computational Hydraulics Inc. is also acknowledged for PCSWMM software license.

- The authors declare to have no real or perceived financial conflicts of interests.

- Data supporting this research are available from the municipality used as the case-study, with agreements requirement for use, and are not accessible to the public or research community directly. Access could be requested through an official data sharing agreement.

- The optimization model supporting this research is available from Jamie M. Brescol from Tetra Tech CSO. Access could be requested through an official data sharing agreement.

This article is protected by copyright. All rights reserved. 


\section{References}

Altobelli, M., Cipolla, S. S., \& Maglionico, M. (2020). Combined application of real-time control and green technologies to urban drainage systems. Water, 12(12), 3432. https://doi.org/10.3390/w12123432.

Alves, A., Sanchez, A., Vojinovic, Z., Seyoum, S., Babel, M., \& Brdjanovic, D. (2016). Evolutionary and holistic assessment of green-grey infrastructure for CSO reduction. Water, 8(9), 402-417. https://doi.org/10.3390/w8090402.

Autixier, L., Mailhot, A., Bolduc, S., Madoux-Humery, A. S., Galarneau, M., Prevost, M., \& Dorner, S. (2014). Evaluating rain gardens as a method to reduce the impact of sewer overflows in sources of drinking water. The Science of the Total Environment, 499, 238-247. https://doi.org/10.1016/j.scitotenv.2014.08.030.

Bi, E. G., Monette, F., Gasperi, J., \& Perrodin, Y. (2015). Assessment of the ecotoxicological risk of combined sewer overflows for an aquatic system using a coupled "substance and bioassay" approach.

Environmental Science and Pollution Research, 22(6), 4460-4474. https://doi.org/10.1007/s11356-014-3650-9.

Bilodeau, K. (2018). Intégration du contrôle en temps réel des bassins d'orage dans une stratégie globale d'adaptation aux changements climatiques (Master's thesis).

(https://corpus.ulaval.ca/jspui/handle/20.500.11794/30267). Québec, Canada: Université Laval.

Brasil, J., Macedo, M., Lago, C., Oliveira, T., Júnior, M., Oliveira, T., \& Mendiondo, E. (2021). Naturebased solutions and Real-time control: Challenges and opportunities. Water, 13(5), 651. https://doi.org/10.3390/w13050651

Burian, S. J., Nix, S. J., Durrans, S. R., Pitt, R. E., Fan, C.-Y., \& Field, R. (1999). Historical development of wet-weather flow management. Journal of Water Resources Planning and Management, 125(1), 3-13. https://doi.org/10.1061/(ASCE)0733-9496(1999)125:1(3).

Carbone, M., Garofalo, G., \& Piro, P. (2014). Decentralized real time control in combined sewer system by using smart objects. Procedia Engineering, 89, 473-478. https://doi.org/10.1016/j.proeng.2014.11.237

Chaosakul, T., Koottatep, T., \& Irvine, K. (2013). Low Impact Development modeling to assess localized flood reduction in Thailand. Journal of Water Management Modeling, https://doi.org/10.14796/jwmm.r246-18.

Cumputational Hydraulics International (CHI) (2020). PCSWMM (Version 7.2.2785). Toronto, Canada.

Canadian Standard Association (CSA) (2018). Design of Bioretention Systems (W200-18). Standards

Council of Canada.

Dagenais, D., Paquette, S., Thomas, I., \& Fuamba, M. (2014). Implantation en milieu urbain de systèmes végétalisés de contrôle à la source des eaux pluviales dans un contexte d'adaptation aux changements climatiques : balisage des pratiques québécoises, canadiennes et internationales et développement d'un cadre d'implantation pour les municipalités du Sud du Québec (Rep. 551004-XXI). Montreal, Canada : Chaire en paysage et environnement (CPEUM), École d'architecture de paysage, Faculté de l'Aménagement, Université de Montréal.

Dirckx, G., Schütze, M., Kroll, S., Thoeye, C., De Gueldre, G., \& Van De Steene, B. (2011). Cost-

efficiency of RTC for CSO impact mitigation. Urban Water Journal, 8(6), 367-377. https://doi.org/10.1080/1573062X.2011.630092.

Dong, X., Guo, H., \& Zeng, S. (2017). Enhancing future resilience in urban drainage system: Green versus grey infrastructure. Water research, 124, 280-289. https://doi.org/10.1016/j.watres.2017.07.038.

Eberhart, R., \& Kennedy, J. (1995). Particle swarm optimization. Proceedings of the IEEE International Conference on Neural Networks, 4, 1942-1948. Perth, Australia.

Eckart, K., McPhee, Z., \& Bolisetti, T. (2017). Performance and implementation of low impact development-a review. Science of the Total Environment, 607, 413-432. https://doi.org/10.1016/j.scitotenv.2017.06.254.

Entem, S., Lahoud, A., Yde, L., \& Bendsen, B. (1998). Real time control of the sewer system of Boulogne Billancourt-A contribution to improving the water quality of the Seine. Water Science and Technology, 37(1), 327332. https://doi.org/10.1016/S0273-1223(97)00785-3.

Fletcher, T. D., Shuster, W., Hunt, W. F., Ashley, R., Butler, D., Arthur, S., Trowsdale, S., Barraud, S., Semadeni-Davies, A., \& Bertrand-Krajewski, J.-L. (2015). SUDS, LID, BMPs, WSUD and more - The evolution and application of terminology surrounding urban drainage. Urban Water Journal, 12(7), 525-542. https://doi.org/10.1080/1573062X.2014.916314.

Frehmann, T., Nafo, I., Niemann, A., \& Geiger,W. (2002). Storm water management in an urban catchment: Effects of source control and real-time management of sewer systems on receiving water quality. Water Science and Technology, 46(6-7), 19-26. https://doi.org/10.2166/wst.2002.0658.

This article is protected by copyright. All rights reserved. 
Frey, J., Wilson, J., Henthorn, P., Schaefer, R., Montestruque, L., \& LaRose, M. (2013). South Bend CSO long term control plan optimization: Comparison of grey-only vs. grey-green infrastructure least-cost solutions. Proceedings of the Water Environment Federation, 2013(18), 1090-1110.

Fu, X., Goddard, H., Wang, X., \& Hopton, M. E. (2019). Development of a scenario-based stormwater management planning support system for reducing combined sewer overflows (CSOs). Journal of environmental Management, 236, 571-580. https://doi.org/10.1016/j.jenvman.2018.12.089.

Fuchs, L., \& Beeneken, T. (2005). Development and implementation of a real-time control strategy for the sewer system of the city of Vienna. Water Science and Technology, 52(5), 187-194. https://doi.org/10.2166/wst.2005.0133.

García, L., Barreiro-Gomez, J., Escobar, E., Téllez, D., Quijano, N., \& Ocampo-Martinez, C. (2015). Modeling and real-time control of urban drainage systems: A review. Advances in Water Resources, 85, 120-132, https://doi.org/10.1016/j.advwatres.2015.08.007.

Gonsalves, T., \& Egashira, A. (2013). Parallel swarms oriented particle swarm optimization. Applied Computational Intelligence and Soft Computing, 2013, ID 756719. https://doi.org/10.1155/2013/756719

Jean, M.-È., Duchesne, S., Pelletier, G. \& Pleau,M. (2018). Selection of rainfall information as input data for the design of combined sewer overflow solutions. Journal of Hydrology, 565, 559-569. https://doi.org/10.1016/j.jhydrol.2018.08.064

Joseph-Duran, B., Maruejouls, T., Khiem Ly, D., Monseguer, J., \& Cembrano, G. (23-26 Sept. 2018). Comparison of volume-based and pollution-based model-predictive controllers for combined sewer network regulation. In $11^{\text {th }}$ International Conference on Urban Drainage Modelling, Palermo, Italy.

Joshi, P., Leitão, J. P., Maurer, M., \& Bach, P. M. (2020). Not all SuDS are created equal: Impact of different approaches on Combined Sewer Overflows. Water Research, 191, 116780. https://doi.org/10.1016/j.watres.2020.116780.

Kroll, S. (2019). Design of Real-Time Control Strategies for Combined Sewer Networks (Doctoral dissertation). (https://lirias.kuleuven.be/2850591?limo=0) Leuven, Belgium: KU Leuven.

Lewellyn, C. J. (2018). Mitigating Risk and Increasing Resilience Through Adaptive Green Infrastructure (Doctoral dissertation). (https://search.proquest.com/dissertations-theses/mitigating-risk-increasing-resiliencethrough/docview/2160930279/se-2?accountid=11605). Ann Arbor, MI: Villanova University.

Liao, Z., Zhang, G., Wu, Z., He, Y., \& Chen, H. (2015). Combined sewer overflow control with LID based on SWMM: an example in Shanghai, China. Water Science and Technology, 71(8), 1136-1142. https://doi.org/10.2166/wst.2015.076.

Lucas, W. C., \& Sample, D. J. (2015). Reducing combined sewer overflows by using outlet controls for Green Stormwater Infrastructure: Case study in Richmond, Virginia. Journal of Hydrology, 520, 473-488, https://doi.org/10.1016/j.jhydrol.2014.10.029.

Lund, N. S. V., Borup, M., Madsen, H., Mark, O., Arnbjerg-Nielsen, K. \& Mikkelsen, P. S. (2019). Integrated stormwater inflow control for sewers and green structures in urban landscapes. Nature Sustainability, 1-8. https://doi.org/10.1038/s41893-019-0392-1.

Lund, N. S. V., Falk, A. K. V., Borup, M., Madsen, H., \& Steen Mikkelsen, P. (2018). Model predictive control of urban drainage systems: A review and perspective towards smart real-time water management. Critical Reviews in Environmental Science and Technology, 1-61, https://doi.org/10.1080/10643389.2018.1455484.

Madoux-Humery, A. S., Dorner, S. M., Sauve, S., Aboulfadl, K., Galarneau, M., Servais, P., \& Prevost, M. (2015). Temporal analysis of $E$. coli, TSS and wastewater micropollutant loads from combined sewer overflows: implications for management. Environmental Science : Processes \& Impacts, 17(5), 965-974, https://doi.org/10.1039/c5em00093a.

Mailhot, A., Bolduc, S., Talbot, G., \& Khedhaouiria, D. (2014). Gestion des eaux pluviales et changements climatiques: Version finale. Quebec, Canada : INRS, Centre Eau Terre Environnement.

Maiolo, M., Palermo, S. A., Brusco, A. C., Pirouz, B., Turco, M., Vinci, A., Spezzano, G., \& Piro, P. (2020). On the use of a real-time control approach for urban stormwater management. Water, 12(10), 2842. https://doi.org/10.3390/w12102842

Ministère de l'Environnement et de la Lutte contre les Changements Climatiques (MELCC) (2014). Position sur l'application des normes pancanadiennes de débordement des réseaux d'égout municipaux. (https://www.environnement.gouv.qc.ca/eau/eaux-usees/ouvrages-municipaux/position-ministere.htm)

Montalto, F., Behr, C., Alfredo, K., Wolf, M., Arye, M., \& Walsh, M. (2007). Rapid assessment of the cost-effectiveness of low impact development for CSO control. Landscape and Urban Planning, 82(3), 117-131. https://doi.org/10.1016/j.landurbplan.2007.02.004

This article is protected by copyright. All rights reserved. 
Nielsen, N. H., Ravn, C., \& Mølbye, N. (28 Jun- 1 Jul. 2010). Implementation and design of a flexible RTC strategy in the sewage system in Kolding, Denmark, In: NOVATECH 2010, Lyon, France: The Graie.

Oberascher, M., Kinzel, C., Kastlunger, U., Kleidorfer, M., Zingerle, C., Rauch, W., \& Sitzenfrei, R. (2021). Integrated urban water management with micro storages developed as an IoT-based solution-the smart rain barrel. Environmental Modelling \& Software, 139, 105028. https://doi.org/10.1016/j.envsoft.2021.105028

Osseyrane, M. (1-3 Dec. 2014). Débordements des réseaux unitaires État de la situation. Oral presentation in Congrès Infra 2014, Centre d'expertise et de recherche en infrastructures urbaines, Montreal, Canada.

Passerat, J., Ouattara, N. K., Mouchel, J.-M., Rocher, V., \& Servais, P. (2011). Impact of an intense combined sewer overflow event on the microbiological water quality of the Seine River. Water Research, 45(2), 893-903. https://doi.org/10.1016/j.watres.2010.09.024.

Patwardhan, A. S., Hare, J. T., Jobes, T., \& Medina, D. (15-19 May 2005). Analyzing potential benefits of low impact development in reducing combined sewers overflows. In: Impacts of Global Climate Change, American Society of Civil Engineers (ASCE): Anchorage, Alaska. https://doi.org/10.1061/40792(173)156

Piro, P., Turco, M., Palermo, S. A., Principato, F., \& Brunetti, G. (2019). A Comprehensive Approach to Stormwater Management Problems in the Next Generation Drainage Networks. In The Internet of Things for Smart Urban Ecosystems, edited, pp. 275-304, Springer.

Pleau, M., Colas, H., Lavallee, P., Pelletier, G., \& Bonin, R. (2005). Global optimal real-time control of the Quebec urban drainage system. Environmental Modelling \& Software, 20(4), 401-413. https://doi.org/10.1016/j.envsoft.2004.02.009.

Radinja, M., Comas, J., Corominas, L., \& Atanasova, N. (2018). Multi-criteria evaluation of sustainable urban drainage systems. In: G. Mannina (Eds.), New Trends in Urban Drainage Modelling: UDM 2018 (pp.266274). Green Energy and Technology, Springer, Cham. https://doi.org/10.1007/978-3-319-99867-1_45

Rossman, L. (2015). SWMM 5.1 Storm water management model user's manual. Cincinnati, OH: US Environmental Protection Agency.

Rossman, L., \& Huber, W. (2016). Storm Water Management Model Reference Manual Volume III - Water Quality. Cincinnati, OH, 45268: US Environmental Protection Agency, Office of Research and Development, National Risk Management Laboratory.

Schuetze, M., Erbe, V., Haas, U., Scheer, M. \& Weyand, M. (2008). Sewer system real-time control supported by the M180 guideline document. Urban Water Journal, 5(1), 69-78. https://doi.org/10.1080/15730620701754376.

Schütze, M., Campisano, A., Colas, H., Schilling, W., \& Vanrolleghem, P. A. (2004). Real time control of urban wastewater systems - where do we stand today? Journal of Hydrology, 299(3-4), 335-348.

https://doi.org/10.1016/j.jhydrol.2004.08.010.

Sebti, A., Fuamba, M., \& Bennis, S. (2016). Optimization model for BMP selection and placement in a combined sewer. Journal of Water Resources Planning and Management, 142(3), 04015068. https://doi.org/10.1061/(asce)wr.1943-5452.0000620.

Seggelke, K., Löwe, R., Beeneken, T., \& Fuchs, L. (2013). Implementation of an integrated real-time control system of sewer system and waste water treatment plant in the city of Wilhelmshaven. Urban Water Journal, 10(5), 330-341. https://doi.org/10.1080/1573062x.2013.820331.

Shishegar, S., Duchesne, S., \& Pelletier, G. (2018). Optimization methods applied to stormwater management problems: a review. Urban Water Journal, 15(3), 276-286.

https://doi.org/10.1080/1573062X.2018.1439976.

Smullen, J. T., Myers, R. D., \& Reynolds, S. K. (2008). A green approach to combined sewer overflow control: source control implementation on a watershed scale. Proceedings of the Water Environment Federation, 2008(6), 714-725.

Stovin, V. R., Moore, S. L., Wall, M., \& Ashley, R. M. (2013). The potential to retrofit sustainable drainage systems to address combined sewer overflow discharges in the Thames Tideway catchment. Water and Environment Journal, 27(2), 216-228. https://doi.org/10.1111/j.1747-6593.2012.00353.x

Tavakol-Davani, H., Burian, S. J., Devkota, J., \& Apul, D. (2015). Performance and cost-based comparison of green and gray infrastructure to control combined sewer overflows. Journal of Sustainable Water in the Built Environment, 2(2), 04015009. https://doi.org/10.1061/JSWBAY.0000805.

Tibbetts, J. (2005). Combined sewer systems: down, dirty, and out of date. Environmental Health Perspective, 113(7), 465-467. https://doi.org/10.1289/ehp.113-a464.

Torres, M. N., Zhu, Z., \& Rodríguez Sánchez, J. P. (2018). A prioritization tool for SUDS planning in large cities by coupling an urban drainage model with mixed integer linear programming. In: G. Mannina (Eds.), New

This article is protected by copyright. All rights reserved. 
Trends in Urban Drainage Modelling: UDM 2018 (pp.266-274). Green Energy and Technology, Springer, Cham. https://doi.org/10.1007/978-3-319-99867-1_25.

Wang, M., Zhang, D., Adhityan, A., Ng, W. J., Dong, J., \& Tan, S. K. (2016). Assessing cost-effectiveness of bioretention on stormwater in response to climate change and urbanization for future scenarios. Journal of Hydrology, 543, 423-432. https://doi.org/10.1016/j.jhydrol.2016.10.019.

Xu, W. D., Burns, M. J., Cherqui, F., \& Fletcher, T. D. (2020). Enhancing stormwater control measures using real-time control technology: a review. Urban Water Journal 18(2), 101-14. https://doi.org/10.1080/1573062X.2020.1857797.

Xu, W. D., Fletcher, T. D., Duncan, H. P., Bergmann, D. J., Breman, J., \& Burns, M. J. (2018). Improving the multi-objective performance of rainwater harvesting systems using real-time control technology. Water, 10(2), 147. https://doi.org/10.3390/w10020147.

This article is protected by copyright. All rights reserved. 